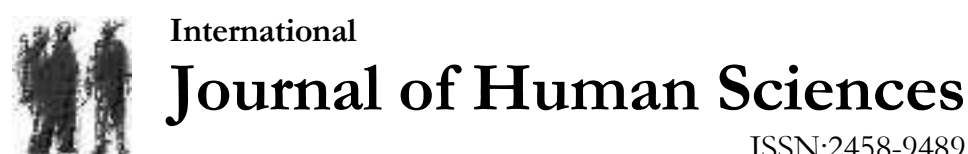

Volume 17 Issue 3 Year: 2020

\section{Computer-aided music education and musical creativity}

\author{
Adem $\mathrm{Maba}^{1}$
}

\begin{abstract}
It has become an absolute necessity to integrate informatics into educational activities as it is in all areas of life by using innovative teaching methods in the globalized world. As in other fields, developing the knowledge and experience of students by using information technologies in music education should be one of the principles of today's education system. Utilizing computer technologies and software applications especially in the areas of music perception in order to promote the creativity and knowledge contributes to an increase in students' positive attitude towards the course by enriching the context of the course. If a complex and difficult topic, such as composing music, which is one of the upper dimensions of creativity, is supported by the computer technologies and software applications, it will obviously help students to understand the process that is very demanding and create a product. In addition, many subjects that are difficult and abstract for everyone to conceive can be made easier by means of the computer technologies and software. When the educational programs developed in recent years are examined, it can be seen that informatics is included in many learning outcomes and activities aiming to improve musical creativity. In this study, detailed information about the effect of computer-aided education on the development of musical creativity is given. Suggestions for future studies are also presented.
\end{abstract}

Keywords: Computer-aided education, creativity, musical creativity.

\subsection{Computer-Aided Music Education}

\section{Introduction}

Computer technology, which has become an indispensable tool in education and training activities in recent years, is now actively used in music education. Rapidly changing and developing technology also affects education and educational institutions as it also does in daily life (Tecimer, 2006). Computer-aided education is a process in which students interact with the courses which are programmed with computers, while the teacher is the guide and the computers assume the role of the environment. The main aim is to enrich the course by using different materials such as computers and to ensure the continuity of learning (Engin et al., 2010). Students are active in the computerassisted teaching process and the teacher is the mentor. When modern education models are examined, it is seen that computer-assisted education provides many advantages (Tecimer, 2006). The opportunity of having flexibility of using the computers in various places like in the library, at home, at school, also the chance of revision anywhere and the capability of audio visual usage can increase the retention of learning for the students (Uşun, 2000).

\footnotetext{
${ }^{1}$ Ph.D., Dokuz Eylul University, Buca Faculty of Education, Music Education Department, ademmaba@gmail.com (iD) Orcid ID: 0000-0002-2650-2223
} 
Computer-aided education provides many advantages and benefits to teachers. For instance, presentations, slides, videos, experiments, music, etc. related to the subject of the course can be given to students in order to promote a better understanding of the subject. Besides, by having the students watch the videos of the high-cost experiments that pose a risk to laboratories, some shortcomings like the lack of laboratories can be compensated. Computers can easily be used in the narration of common subjects in different disciplines. Computer-aided teaching provides various benefits such as the increase of students' participation in the course, more efficient use of it, and the facilitation of the assessment and evaluation (Mercan et al., 2009).

In recent years, developments in music technologies have brought about a different dimension in music education. These developments provide not only teachers but also students with a lot of conveniences. The aim of the use of music software in education is to increase students' motivation, improve scientific thinking skills, support group activities in the classroom, expand the teaching methods, develop students' learning skills, support the development of advanced thinking skills and encourage them to establish hypotheses by finding solutions to the problems they encounter (Demirel et al., 2001).

Music teachers utilize computers, the internet, electronic musical instruments, televisions, videos, computer programmes, sound systems, and various other devices in music classes to develop students' personal academic skills and increase their creativity and motivation. Webster (2007), stressed that teachers should actively use music technologies and applications in their courses in order to facilitate learning. The main purpose of the use of information technologies in music classes should make sure that students are more active with recent approaches by showing positive attitudes towards music courses unlike conventional methods in music education. (Tecimer, 2006). When the developments in music technologies are examined, it will be seen that many devices, instruments, programs and software have been produced and by means of these programs and software, it is now very easy to accomplish the job large orchestras can do with a merely single computer by creating small studios at home (Arapgirlioğlu, 2003). Composing and note writing programs allow individuals to listen to the music they create, and help them to use many sensory organs at the same time. Another advantage of these programs is the ability to instantly see and correct errors while listening to the music they create (Wilkinson, 1997). Music lessons can become more attractive for children since they can be more active in some theoretical subjects, especially in musical notes. Their learning outcome can also last longer. In particular, teaching some musical note writing programs such as "Encore and Finale" can contribute considerable support to the development of children's composition and creativity (Levendoğlu, 2004; Sevinc \& Koldemir, 2008). As seen in literature, the rapidly evolving technology has become an indispensable part of the education sector as in all areas. From the pre-school period on, the use of computers are quite common in order to enrich the educational environment in many educational levels and disciplines and increase the persistence of teaching. Similarly, the personnel who work in information technologies related to the course curriculum develop educational software/applications (Levendoğlu, 2004).

Nowadays the use technology in music education has become quite common, and experimental studies on this issue show that this important step in music education has revealed positive results. In this respect, the following studies in the literature are provided to show the effects of computer-aided education on music education.

Schroth et al. (2009) have revealed that talented students in the musical sphere may not be in all capable of creating/composing, listening and performing (playing), which are the most important factors that make up music. They emphasized that the musical education in many private and state schools focus on developing the musicality and technical knowledge of special talented individuals; nonetheless, composing is an important tool which supports the general musical development of the talented child. The teaching of composing allows students to actively participate in small groups depending on their individual skills and interests. Schroth et al. (2009) state that when the interest areas of talented children, readiness levels and learning profiles are taken into account, the design of composing activities or endorsing of the composing activities is an important tool in terms of 
developing these talented children to be versatile individuals. Another point made by Schroth et al. (2009) is that the talented individuals who are unaware of their composing and general music skills can compensate for their musical developments when they are provided some composing software/applications by their teachers and families. Notation programs: Finale and Sibelius, recording software: Audacity, music sequencing programs: GarageBand, Intuem and Cakewalk (Programs available with graphical notation), beginning composition programs: Making Music and TuneBlocks, music and composing sharing programs: VermontMIDI are suitable for this (Schroth et al., 2009).

Webster (2007), on the other hand, emphasized the important increase in the power and usability of hardware and software for music education, music teaching and learning between19902000, and also emphasized that teachers lag behind in adaptation and using these resources. Nonetheless, he stated that many associations and organizations around the world give importance to studies related to music technology and research; that is why the rate of the research on this area continues to increase more rapidly than ever. According to Webster (2007), more detailed studies are needed for the use of technology in music education. Especially more in-depth studies on gender and technology, equality in access to the best resources, and the real impact of technology on professional musicians and the public in long-term learning will help to identify and address the deficiencies in the field (Webster, 2007).

In his research on computer and music education in Sweden, Bresler (2007) determined what digital music equipment is in class activities and which equipment is used and applied by teachers. The results of the study showed that the activities performed with music technology were divided into two main headings. The first of these titles is that music is used as an external tool to achieve the objectives of the program, and the second is that music technology is assimilated with internalization. The study shows that girls use the computer less than boys apart from making music, and they also tend to see making creative music via computer and music technologies is not a computer activity but a musical activity instead. The results showed that students working with computer and music technology (especially girls) became aware of their own capacities and abilities, and improved their personality and attitude towards music lessons. One of the most important results of the study shows that music production via music technology plays an important role not only in musical development but also in achieving the goals of general and basic training (Bresler, 2007).

In his study, Beckstead (2001) emphasized that although technological advances have made composing easier, music educators tend to legitimize traditional methods rather than using these technological advances. However, MIDI technology has provided students with richer learning opportunities rather than traditional (paper-pen) composing method that once provided limited possibilities. One of the results of the study is that teachers look beyond the efficiency of basic technologies and look for ways to reassess and transform IT application with the help of computers.

In their study, Seddon and O'Neill (2003), revealed potential differences in the paths, methods and strategies of adolescents with and without musical instrument education by interacting with computer-based composition. For the implementation phase of the study, a total of forty-eight adolescents aged 13-14 years from a secondary school in the northwest of England were included in the sample group and they were subjected to 2 -session computer-aided composition training for 30 minutes. Twenty-five of the students have a musical experience of about 4 years, while the remaining 23 students do not have any musical instrument background. In the study, Yamaha PSR530 digital keyboard was connected to the computer to compose and a composition program called Cubase Score was used. As a result of the study, it has been shown that a number of different strategies were adopted by adolescents and these strategies are part of three meta-approaches (production, expression and depth). It was found out that there were differences in the discovery/invention/ new idea stage of composition and that those who received formal musical instrument training could easily pass this process. The results suggest that individuals with previous experience in musical instruments tend to conduct less experimentation with the possibilities offered by the computer than those who did not have a musical instrument experience before, which supports previous academic studies. 
Nilsson and Folkestad (2005) emphasizes that different forms of music have become a key factor in the daily lives of today's children who live in a world where technological changes are rapidly occurring. In their study, they aimed to describe and explain the 2-year experimental process of 6-8year-old Swedish children who produce music with synthesizer computer software and the creative processes of computer-based composition at the end of this process. For this purpose, computerized keyboards and computer-based music editing programs were used. In the study, MIDI files were systematically recorded at the end of each activity and a total of 76 recordings were obtained. In addition, interviews and observations were made for each participant. As a result of analyses, five different variations are defined and these are compositions, synthesizer and computer, personal fantasies and emotions, playing of the instrument, the music itself and task. According to another finding of the study, even the youngest children in western countries obtain music knowledge and skills through mass communication/media at home, at school or in their spare time. Nowadays, young children can listen to music without any adult intervention and create their own music using easy-to-use computer music software (Nilsson \& Folkestad, 2005).

Reese and Hickey (1999), emphasized the importance of determining how and to what extent the internet and music technologies such as MIDI can be used to support the education of music teacher in collaborative and distance learning environments. Researchers have implemented an enriched program for teaching and learning music through a technology-based composition. Reflecting the experiences of the researchers, the most important goals of the study is to encourage other educators to participate actively in similar projects and to increase the knowledge and skills of music teacher candidates and music teachers. Using the internet, information technologies and tools regularly both in the classroom and in the education of prospective teachers, is one of the important findings of the study that provides a great benefit to teachers and students.

Sevinç and Koldemir (2008) carried out a study to observe whether the music teachers who are teaching Informatics Supported Music Courses in Anatolian Fine Arts High Schools are able to use informatics supported music software and programs or not. In order to collect data, the researchers gathered data from 20 music teachers who were teaching IT Supported Music courses in 20 different Anatolian Fine Arts High Schools by means of survey. As a result of the analyzes, it is seen that the teachers who teach Informatics-Supported Music courses are familiar with the audio technologies and music technologies at an adequate level, and the physical facilities of the schools are also sufficient. Another remarkable finding of the study is that 18 music teachers, except two, have knowledge and experience about information technologies with their own personal efforts and studies. The reason for this is that the higher education institutions providing music education in our country are insufficient in the field of "Computer-Aided Music Education". In the Informatics Supported Music courses, the differences in the choice of programs for teachers to use (not using a standard curriculum) cause problems about information sharing. The problems like the original music software used for the courses are foreign, the computer hardware is expensive and teachers do not have Turkish language options are some of the results of the study.

In his study, Nart (2016) has emphasized the role of the teacher and the change of classical teaching methods since the 21st century. In the study, the software which was used in music education and the new software which could also be used were mentioned. The researcher has gathered these software under five main headings: instructional software, exercise and application software, game software, notation software, and ranking and recording software. At the end of the study, teachers were provided significant suggestions about using music technologies which were developed for music lessons. 
Maba, A. (2020). Computer-aided music education and musical creativity. Journal of Human Sciences, 17(3), 822-830. doi:10.14687/jhs.v17i3.5908

\subsection{Computer Aided Music Education and Musical Creativity}

Music creativity, one of the types of creativity, is the capacity to produce new, original thought and products related to music (Piji, 2003; Swanwick \& Tilmann, 1986). According to Webster (2002), musical creativity takes place in a thought process of an active and structured sound in order to produce new musical piece. According to Webster' model (2002), the creative thinking process in music consists of 3 stages; purpose of the musical piece, thought process, creative pieces. Elliott, (1989) approached the process as the producer, production process and the new piece that emerged eventually; and claimed that these processes were completely intertwined and interrelated. According to Burnard (2007), musical creativity occurs in different contexts with different tools, technologies, rules, and ritual practices. According to Stenberg and Lubart (1996), creativity is the ability to produce a new and suitable product. Likewise, musical creativity is the process of producing a product or, put differently, musical piece, composition or improvisation, interpretation, remix, recording or production (Mazzola et al., 2011: 145). The main dimensions of musical creativity are composing and improvisation. Creative thinking can be developed with an educational environment in which appropriate learning and teaching activities are designed. Composing; the musical breadth (musical ideas or new musical ideas) is closely related to musical flexibility (tempo, musical dynamics, and movement within musical parameters) and originality (new and unique musical expressions) (Webster et al., 1988). When musical creativity is considered, it can be seen that it starts to develop from early childhood, so it is very important to start the training on musical creativity at an early age and continue in the later years (Küpana, 2013; Malkoç, 2014). Music teachers need to develop the children's ability to think creatively in music, rather than focusing on children being creative in education (Hickey \& Webster, 2001).

Musical creativity and technology-supported education in Turkey are intertwined in the curriculum for music classes 1-8 as a learning domain (MEB, 2007). In particular, when the 5th and 6th-grade annual music course plan is examined, it is seen that the objectives to be achieved are stated below:

The student

- Uses basic music notation symbol fonts and elements,

- Distinguishes the length and shortness properties of the learned sounds,

- Graphically displays the sound loudness in music,

- Distinguishes the high pitch and bass properties of the sounds,

- Performs his own tunes,

- Applies Prosody rules,

- Applies the rules of rhythm,

- Applies the music and speed steps,

- Accompanies the melodies with his/her own rhythm pattern,

- Recognizes and distinguishes the music sentence,

- Performs his/her own tunes. Displays his/her music,

- Uses information technologies in music research and studies,

- Recognizes different types of music by using music technologies

- Makes use of music technologies to create his/her own archive,

- Recognizes music technologies,

- Uses music technologies (MEB, 2017)

When the objectives to be achieved above are analyzed, it is seen that achievements in information technology and creativity subjects are included in music education. By associating these achievements with the subject of prosody, it may be possible to teach via the help of notes writing/editing programs that can be used on a computer, and create a product eventually. In addition to this, with the help of information technology, students will be provided the opportunity to learn music permanently, so music lessons will be more attractive for them since they will be more active in note learning process and some theoretical subjects like rhythmic and height differences of sounds. 
Especially the teaching of some music notation software like "Encore" and "Finale" contributes remarkably to children's further development of creativity and their composition skills. (Levendoğlu, 2004; Sevinç \& Koldemir, 2008).

İnevitably, music education catches the era and updates itself via the current advancements of technology in the century which is defined as the age of technology and information (Levendoğlu, 2004). Today, with the developing technology, it is seen that many devices, instruments, programs, and software which contribute to the musical creativity have been produced (Arapgirlioğlu, 2003). By means of these programs, small studios can be created at home and it is approximately possible to achieve the same performance with a single computer instead of great orchestras (musical ensembles). Because of the programs developed through the advancements in music technologies, classical music education in schools is no longer the only alternative. The software which is designed for various areas of music such as sound education, instrument teaching, music theory education, harmony and orchestration has an important role to play to for both music teachers and students by enriching their learning environment (Levendoğlu, 2004; Webster, 2012). Teachers can support listening, performance and composition using a variety of software, web-based resources and various music technologies. In addition, they can use the music technologies to model the musical concepts they teach, improve the evaluation process, have students search for and access teaching resources and communicate with them (DCMS, 2011). When technological tools are examined, it can be seen that there is a wide range of equipment to support the development of musical skills, knowledge and understanding. By using this equipment, it is also possible to offer a wider range of sound in live performances in the classroom and music composition (DCMS, 2011). Those composition/note writing programs which are useful to individuals to listen to the music they create also helps them to use and develop many senses at the same time (Webster, 2007). Another advantage of these programs is that it allows people to see and correct their mistakes instantly while listening to the music they create (Wilkinson, 1997).

Although research and studies on music technology for music teaching and learning increased from 1990 to 2000, the available publications were limited (Sevinç \& Koldemir, 2008; Webster, 2007). Because of this, the following literature includes the studies on computer-aided music education and the effects of this education on musical creativity.

In his work on new technology and creativity, Crow (2006) details the process of music education programs and provides information about how the process of composing emerged in the UK. According to his research, the concept of creativity in music started to take place in music education programs for the first time in 1992. While music education programs were focused on performance and listening before 1992, and from that date on, composition for 5-14 year- old children was included in general music education programs. The subject of composing in music classes is now at the center of the secondary school curriculum. This research argued that teachers have had difficulties in developing consistent approaches to musical creativity in general music education; furthermore, they have not yet grasped the knowledge and skills to use the new technology appropriately. For this reason, it was also underlined that the music curriculum should be redesigned, developed and funded. While these programs are being redesigned, it was emphasized that it is necessary to touch on the assumptions existing in our current approaches to music education, review the concept of creativity, reassess the role of technology and evaluate the negative effects of school music on some students. The research also stated that the curriculum to be prepared should include: music from the British Isles, the tradition of "Western classical", live or recorded music from different times and cultures, consisting of folk, jazz and popular genres and well-known composers. According to Crow (2006), the aim of music education is to make music more useful, sustainable and valuable for students. In this process, teachers should encourage, develop and correctly evaluate the creative ideas of students. Another point highlighted in the study is that new music technologies may not be able to respond to all problems that may arise while promoting creativity in the classroom.

Burnard (2007) focuses on the relationship between the use of technology and the development of creativity in his work on re-engaging learners through digital technology, regaining 
creativity and promoting pedagogical change in music education. He underlines that the improvements on the curriculum of music education used in the schools with the developing technology and science will also facilitate the development of the creative thinking. The researcher makes suggestions for this change in his study which defines new kinds of relationships between creativity and technology in the curriculum because of the advancements in technology. These suggestions can be seen below:

- The relationship between technology and creativity has been determined by educational administrators depending on "expert research" and promoting an innovative and effective teacher development.

- It is emphasized that through the "technical standards" applied top-down, the current trend towards the dominance of the curriculum and pedagogy should be resisted.

- In addition, progress has been made in empirical studies like this, by identifying the professionalism of music teachers and serious concerns that have undermined their own values since the beginning of the 21 st century.

- It is the promotion of learning through connected learning communities that can play a critical role in providing opportunities for research and knowledge with new technologies to increase teacher confidence and pedagogical change.

In a study by Nielsen (2013), it was stated that music technology courses designed to use the latest music software (MIE and GarageBand) for high school students to improve their musical composition skills became more pronounced in K-12 education. The aim of the study was to evaluate the development of creativity of high school students who attended a music technology course at a Middle Western high school. For this purpose, the main problem question for the research was determined as "How do students and their music teachers define the students' creativity development?" The study group consisted of 2 teachers and 10 students who were taking the course. The data obtained from the study were analyzed under four themes: technological infrastructure, musical background, music preferences, and learning activities. According to the results obtained from the study, the students could not explain their creative thinking skills very well, but it was seen that the teachers defined creativity as a new appropriate original thought and a product as in the original definitions. Based on this definition, teachers stated that music education, which is given with technology support, develops the skills of children, especially creative thinking skills. However, it was stated by the teachers that the students improved themselves to work in collaboration, to make meaningful and constructive feedback on musical compositions and to connect with other disciplines. It also emerged that the study contributed to the students' musical development and that the students' work created opportunities for self and peer reflection. In the light of the results obtained from the study, it has been suggested that new ideas should be developed and encouraged in order to provide a general creative experience as well as the reflection of this to the final product.

In his study on the development of creativity in music lessons, Hickey (2001) depicted the arrangements to support musical creativity. He stated that one of these arrangements was to ensure the use of technology in the classroom. Moreover, he pointed out that the developments in music education technology provide tremendous help to students in processing and creating musical sounds and that technology is more powerful and useful than ever to provide creative musical thinking tools for students.

\section{Conclusion and recommendations for future research}

When the results obtained from the study are examined, it has been determined that there is intensive research on computer-aided music education. In addition, the impact of computer-aided music education on musical creativity has been widely researched in descriptive studies, but it has been also observed that this impact has been revealed with a small number of experimental studies. Studies conducted by Arapgirlioglu, (2003), Levendoglu (2004), Sevinc \& Koldemir (2008), Webster (2007) and Wilkinson (1997) revealed that information technologies that are actively used in music 
education have focused intensively on making music lessons more efficient. It seems that additional studies are needed. In this regard, studies on computer-aided music education can be conducted in the context of various experimental designs, sample groups, methods and data collection tools.

Another finding of the study shows that the developments in music technologies give a different dimension to music education and it provides ease for not only for music teachers and students but also for anyone who is interested in music. This stems from the fact that computers can be used anywhere. Besides they enable the users to repeat as much as they want with audio-visual support. Therefore, the persistence of learning can be achieved for the students with the support of the computer-aided education (Uşun, 2000). In future studies, theoretical and practical studies on music technologies can be carried out.

Musical creativity has been defined by various researchers (Elliott, 1989; Hickey \& Webster, 2001; Piji, 2003; Swanwick \& Tilmann, 1986; Webster, 1988; 2002), in the broadest sense, as the producing a new idea, an innovative and original thought or a product in musical context and expression. In the process of revealing creative product in the musical sense, it is seen that the person has a purpose firstly, and to achieve this, he/she uses divergent and convergent thinking skills during the composition, performance and analysis process. The process of divergent thinking consists of activating skills, proposing creative products in accordance with predisposition and possibilities, preparation, incubation, enlightenment and proof processes. In the convergent thought process, the same creative product setting process is realized in line with aesthetic sensitivity, conceptual understanding and mastery variables. These processes interact with each other fully. At the end of these processes, the creative product emerges as a composition (musical piece), performance or analysis. At the same time, musical development is an important factor in the development of musical creativity. In parallel with cognitive development, this development has been observed as sensory in the first years of life, and in the following years as imitation, games, and learning metacognitive way respectively. In the development of musical creativity, which has become an important concept in the music teaching process, the impact of computer-aided education was revealed with scientific studies (Beckstead, 2001; Crow, 2006; Hickey \& Webster, 2001; Dcms, 2011; Mazzola et al., 2011: 145; Nilsson \& Folkestad, 2005; Reese \& Hickey, 1999; Schroth et al., 2009; Seddon \& O'Neill, 2003; Wilkinson, 1997). In this context, theoretical and practical studies that can support musical creativity should be conducted in future studies.

\section{References}

Arapgirlioğlu, H. (2003). Müzik Teknolojisi ve Yeni Yüzyılda Müzik Eğitimi. Malatya: Cumhuriyetimizin, $80,160-164$.

Beckstead, D. (2001). Will Technology Transform Music Education? Music Educators Journal, 87(6), 44-49.

Bresler, L. (Ed.). (2007). International Handbook of Research in Arts Education (Vol. 16). Springer Science \& Business Media.

Burnard, P. (2000). How Children Ascribe Meaning to Improvisation and Composition: Rethinking Pedagogy in Music Education. Music Education Research, 2(1), 7-23.

Burnard, P. (2007). Reframing creativity and technology: Promoting pedagogic change in music education. Journal of Music, Technology \& Education, 1(1), 37-55.

Crow, B. (2006). Musical creativity and the new technology. Music Education Research, 8(1), 121-130.

DCMS . (2011) . Music Education and the Music Grant: Aspirations, support, and delivery. Department for Culture, Media \& Sport. http://wnw.ks2music.org.uk/do_download.asp?did=29568 [Google Scholar]

Demirel, Ö., Seferoğlu, S. S. \& Yağc1, E. (2001). Ögretim Teknolojileri ve Material Gelistirme, Ankara: Pegem A Yayincilik.

Piji, D. (2003). Müzik öğretmeni adaylarının müzik derslerindeki başarıları ile müzikal yaratıcllıkları arasındaki ilişki.

Elliott, D. J. (1989). The Concept of Creativity: Implications for Music Education. 
Maba, A. (2020). Computer-aided music education and musical creativity. Journal of Human Sciences, 17(3), 822-830. doi:10.14687/jhs.v17i3.5908

Engin, A. O..Tösten, R. ve Kaya, M. D. (2010). Bilgisayar Destekli Eğitim. Kafkas Üniversitesi Sosyal Bilimler Enstitüsü Dergisi, 5, 69-80.

Hickey, M. (2001). Creativity in the music classroom. Music Educators Journal, 88(1), 17-17.

Hickey, M., \& Webster, P. (2001). Creative Thinking in Music. Music Educators Journal, 88(1), 19-23.

Küpana, M. N. (2013). Müzikal Yaratıcılığ1 Geliştiren Yaklaşımlar. Eğitim ve Ögretim Araştırmalar Dergisi Journal of Research in Education and Teaching, Cilt:2 Say1:2 Makale No:03 ISSN: 2146-9199.

Levendoğlu, N. O. (2004). Teknoloji Destekli Çağdaş Müzik Eğitimi. Müzik Öğretmeni Yetistirme Sempozуити Bildirisi, SDÜ, 7-10.

Malkoç, T. (2004). Üstün Yetenekli Çocuklar ve Müzik Eğitimi. I. Türkijye Üstün Yetenekli Cocuklar Kongresi Yayin Dizisi: 2, 168.

Mazzola, G., Park, J., \& Thalmann, F. (2011). Musical Creativity: Strategies and Tools in Composition and Improvisation. Springer Science \& Business Media.

M.E.B. (2007). Bilim ve Sanat Merkezleri Yönergesi. Online: bttp:/ / mevzuat. meb. gov. tr.

M.E.B. (2017). Müzik Dersi (İlkokul ve Ortaokul 1,2,3,4,5,6,7 ve 8. Sınıflar) Öğretim Programı Tanıtım Sunusu. Online:bttps://tegm.meb.gov.tr/

Mercan, M., Filiz, A., Göçer, İ., ve Özsoy, N. (2009). Bilgisayar Destekli Eğitim ve Bilgisayar Destekli Öğretimin Dünyada ve Türkiye'de Uygulamalan. XI. Akademike Bilisim Konferansı Bildirileri.

Nart, S. (2016). Music Software in the Technology IIntegrated Music Education. Turkish Online Joumal of Educational Technology-TOJET, 15(2), 78-84.

Nielsen, L. D. (2013). Developing musical creativity: Student and teacher perceptions of a high school music technology curriculum. Update: Applications of Research in Music Education, 31(2), 54-62.

Nilsson, B., \& Folkestad, G. (2005). Children's Practice of Computer-Based Composition. Music Education Research, 7(1), 21-37.

Reese, S., \& Hickey, M. A. (1999). Internet-Based Music Composition and Music Teacher Education. Journal of Music Teacher Education, 9(1), 25-32.

Schroth, S. T., Helfer, J. A., \& Dammers, R. (2009). Using Technology To Assist Gifted Children's Musical Development. Gifted Child Today, 32(2), 54-61.

Seddon, F. A., \& O’Neill, S. A. (2003). Creative Thinking Processes in Adolescent Computer-Based Composition: An Analysis of Strategies Adopted and the Influence of Instrumental Music Training. Music Education Research, 5(2), 125-137.

Sevinç, S. ve Koldemir, S. (2008). Anadolu Güzel Sanatlar Liselerinde Bilgisayar Destekli Müzik Eğitiminin Kullanılabilme Durumu (Doctoral dissertation, Selçuk Üniversitesi Sosyal Bilimleri Enstitüsü).

Sternberg, R. J., \& Lubart, T. I. (1996). Investing in Creativity. American Psychologist, 51(7), 677.

Tecimer, B. (2006). İnternet ve Yaşam Boyu Müzik Eğitimi. Mǚred, Kış, (15), 8-9.

Türkiye Bilişim Şurası (2004). Bilgi Toplumuna Doğru: Türkiye 2. Bilişim Şurası Sonuç Raporu. 10-11 Mayıs 2004, ODTÜ Kültür ve Kongre Merkezi. Ankara: Türkiye Bilişim Şurası.

Uşun, S. (2000). Dünyada ve Türkiye'de Bilgisayar Destekli Öğretim. Ankara: Pegem A Yayınc1lı.

Webster, P. R. (1987). Refinement of a Measure of Creative Thinking in Music. Applications of esearch in Music Behaviour. C. Madsen\& C. Prickett (Eds.), Tuscaloosa, Alabama: TheUniversity of Alabama Press.

Webster, P. R., Yale, C. \&Haefner, M. (1988). Test-retestreliability of Measures of CreativeThinking in Music for Children with Formal Music Training. Poster Session of MENC Conference: Indianapolis.

Webster, P. R. (2002). Creative Thinking in Music: Advancing a Model. Creativity and MusicEducation. $\mathrm{T}$.

Webster, P. R. (2007). Computer-Based Technology and Music Teaching and Learning: 2000-2005. In International Handbook of Research in Arts Education (pp. 1311-1330). Springer, Dordrecht.

Webster, P. R. (2012). Key Research in Music Technology and Music Teaching and Learning. Journal of Music, Technology \& Education, 4(2-3), 115-130.

Wilkinson, S. R. (1997). Anatomy of a Home Studio: How EverytbingReally Works, from Microphonesto IDI. Hal Leonard Corporation. 